\title{
Microsatellite Instability Is Common in Colorectal Cancer in Native Nigerians
}

\author{
DAVID O. IRABOR ${ }^{1}$, OLAYIWOLA A. OLUWASOLA ${ }^{2}$, OLUFEMI J. OGUNBIYI ${ }^{2}$, OLABIYI G. OGUN ${ }^{2}$, \\ CLEMENT A. OKOLO ${ }^{2}$, MARILENA MELAS ${ }^{3}$, STEPHEN B. GRUBER ${ }^{3,4}$, CHANJUAN SHI $^{5}$ and LEON RASKIN 6 \\ ${ }^{1}$ Department of Surgery, College of Medicine, University of Ibadan, Ibadan, Nigeria; \\ ${ }^{2}$ Department of Pathology, College of Medicine, University of Ibadan, Ibadan, Nigeria; \\ ${ }^{3}$ USC Norris Comprehensive Cancer Center, Los Angeles, CA, U.S.A.; \\ ${ }^{4}$ Department of Preventive Medicine, University of Southern California, Los Angeles, CA, U.S.A.; \\ ${ }^{5}$ Department of Pathology, Microbiology and Immunology, School of Medicine, \\ Vanderbilt University Medical Center and Vanderbilt Ingram Comprehensive Cancer Center, Nashville, TN, U.S.A.; \\ ${ }^{6}$ Division of Epidemiology, School of Medicine, \\ Vanderbilt University Medical Center and Vanderbilt Ingram Comprehensive Cancer Center, Nashville, TN, U.S.A.
}

\begin{abstract}
Background: Colorectal cancer $(C R C)$ is the fifth most common cancer in Africa, with significant differences in incidence, biology and clinical behavior from other populations. Materials and Methods: We studied prevalence and clinicopathological features of microsatellite instability (MSI) and young onset CRC in 83 archival samples from the University of Ibadan, Nigeria. Results: Nigerian cases of CRC were MSI-high in $43 \%$ and MSI-high CRC had significantly lower histological heterogeneity than microsatellite-stable CRC $(20 \%$ vs. $55 \%$ respectively, $p=0.046)$. Presence of signet ring cell differentiation (10$50 \%$ of tumor) was significantly higher in younger patients with CRC $(<50$ years) (odds ratio $(O R)=5.93,95 \%$ confidence interval $(C I)=1.17-29.95, \quad p=0.038)$. Poor differentiation (34\%), invasive growth (96\%), and high prevalence of mucinous (10\%) and signet ring cell adenocarcinomas (4\%) were among distinct features of Nigerian patients with CRC. Conclusion: MSI-high CRC is more common in West Africa and more detailed molecular and genetic analysis is warranted as CRC incidence and mortality continue to increase in the Sub-Saharan Africa.
\end{abstract}

Once a rare cancer type, colorectal cancer (CRC) is now the fifth most common cancer in Africa (1). However, there are

Correspondence to: Leon Raskin, M.Sc., Ph.D., Division of Epidemiology, Vanderbilt University School of Medicine, 2525 West End Avenue, Suite 300, Nashville, TN 37203-1738, USA. Email: leon.raskin@gmail.com

Key Words: Sub-Saharan Africa, molecular pathology, colorectal cancer, Nigeria, MSI. significant differences in incidence rates, tumor biology, and clinical behavior in comparison to other populations. While the total incidence rates are about one-tenth of those in the developed world, CRC occurs at a younger age in Nigerians and rapidly metastasizes (2). The mortality from CRC in Sub-Saharan Africa may be considered as very high, since many patients are diagnosed at late stages and up to $50 \%$ of them do not return for surgical treatment (3). Molecular pathology and genetics of CRC in Africa have not been comprehensively studied. It has been demonstrated that some molecular characteristics of CRC in patients of African descent are different from those in other populations. For example, we have shown distinctive clinicopathological pattern and high prevalence of CRC with high microsatellite instability (MSI-high) (41\%) in Ghanaian patients (4) compared to $15 \%$ in Whites (5). In addition, a unique set of somatic mutations in CRC has been also identified in African-American patients (6). Analysis of genetic and molecular biomarkers, including MSI, is aimed at better understanding CRC biology, as well as improving diagnosis, treatment, and prognosis of CRC in Africa. Our study performed analysis of pathological features and MSI in a series of archival paraffin-embedded CRC samples from the Department of Pathology at the University of Ibadan in Nigeria. The goal of the study was to investigate prevalence and clinicopathological features of MSI-high and youngonset CRC in Nigeria.

\section{Materials and Methods}

Study samples. Archived CRC paraffin-embedded tissue blocks $(n=114)$ were obtained from the Pathology Department of the College of Medicine at the University of Ibadan and private pathology laboratories in the city of Ibadan. The study was 
Table I. Demographic and clinicopathological characteristics of Nigerian colorectal cancer samples by age and microsatellite status.

\begin{tabular}{|c|c|c|c|c|c|c|c|c|}
\hline & & \multirow{2}{*}{$\begin{array}{l}\text { All samples } \\
\quad(\mathrm{n}=83)\end{array}$} & \multicolumn{2}{|c|}{ Age at diagnosis } & \multirow[t]{2}{*}{$p$-Value } & \multirow{2}{*}{$\begin{array}{c}\text { MSS/ } \\
\text { MSI-low } \\
(n=20)\end{array}$} & \multirow{2}{*}{$\begin{array}{l}\text { MSI- } \\
\text { high } \\
(n=15)\end{array}$} & \multirow[t]{2}{*}{$p$-Value } \\
\hline & & & $\begin{array}{c}>50 \text { Years } \\
\quad(\mathrm{n}=45)\end{array}$ & $\begin{array}{c}\leq 50 \text { Years } \\
(\mathrm{n}=37)\end{array}$ & & & & \\
\hline \multicolumn{2}{|l|}{ Age at diagnosis, mean $\pm \mathrm{SD}$, years } & $56 \pm 14.6$ & $64 \pm 8.1$ & $39 \pm 7.7$ & $<0.0001$ & $60 \pm 16.2$ & $53 \pm 15.3$ & 0.2438 \\
\hline \multicolumn{2}{|l|}{ Age at diagnosis, median, years } & $53(16-85)$ & $63(51-85)$ & $40(16-50)$ & - & $64(30-85)$ & $55(19-79)$ & - \\
\hline \multirow[t]{2}{*}{ MSI } & MSS/MSI-L & $20(57 \%)$ & $15(65 \%)$ & $5(45 \%)$ & 0.2733 & - & - & - \\
\hline & MSI-H & $15(43 \%)$ & $8(35 \%)$ & $6(55 \%)$ & & & & \\
\hline \multirow[t]{2}{*}{ Sex } & Female & $43(52 \%)$ & $20(44 \%)$ & $23(62 \%)$ & 0.1099 & $10(50 \%)$ & $5(33 \%)$ & 0.4916 \\
\hline & Male & $40(48 \%)$ & $25(56 \%)$ & $14(38 \%)$ & & $10(50 \%)$ & $10(67 \%)$ & \\
\hline \multirow[t]{4}{*}{ Tumor location } & Proximal colon & $15(23 \%)$ & $11(32 \%)$ & $5(15 \%)$ & 0.2912 & $4(27 \%)$ & $4(27 \%)$ & 1.0000 \\
\hline & Distal colon & $7(11 \%)$ & $3(9 \%)$ & $4(13 \%)$ & & $3(20 \%)$ & $2(13 \%)$ & \\
\hline & Rectum & $43(66 \%)$ & $20(59 \%)$ & $23(72 \%)$ & & $8(53 \%)$ & $9(60 \%)$ & \\
\hline & Colon, unspecified & 16 & 11 & 5 & & 5 & - & \\
\hline \multirow[t]{5}{*}{ Stage } & Stage I & $1(4 \%)$ & $1(7 \%)$ & - & 0.1531 & - & - & 1.0000 \\
\hline & Stage II & $10(37 \%)$ & $6(40 \%)$ & $4(33 \%)$ & & $4(57 \%)$ & $1(100 \%)$ & \\
\hline & Stage III & $8(30 \%)$ & $6(40 \%)$ & $2(17 \%)$ & & $3(43 \%)$ & - & \\
\hline & Stage IV & $8(30 \%)$ & $2(13 \%)$ & $6(50 \%)$ & & - & - & \\
\hline & Unknown & 56 & 30 & 25 & & 13 & 14 & \\
\hline \multirow[t]{3}{*}{ Specimen type } & Resection & $54(65 \%)$ & $15(34 \%)$ & $11(31 \%)$ & 0.8025 & $14(70 \%)$ & $8(62 \%)$ & 0.3126 \\
\hline & Biopsy & $26(31 \%)$ & $29(66 \%)$ & $24(69 \%)$ & & $6(30 \%)$ & $7(58 \%)$ & \\
\hline & Unknown & $3(4 \%)$ & - & - & & - & - & \\
\hline \multirow[t]{5}{*}{ Histological type } & Adenocarcinoma, NOS & $63(76 \%)$ & $36(82 \%)$ & $26(70 \%)$ & 0.4123 & $15(75 \%)$ & $11(73 \%)$ & 1.0000 \\
\hline & Medullary adenocarcinoma & $2(2 \%)$ & - & $2(5 \%)$ & & $1(5 \%)$ & - & \\
\hline & Mucinous adenocarcinoma & $8(10 \%)$ & $5(11 \%)$ & $3(8 \%)$ & & $3(15 \%)$ & $2(13 \%)$ & \\
\hline & Signet ring cell carcinoma & $3(4 \%)$ & $1(2 \%)$ & $2(5 \%)$ & & $1(5 \%)$ & $1(7 \%)$ & \\
\hline & Other & $7(8 \%)$ & $3(7 \%)$ & $4(12 \%)$ & & - & $1(7 \%)$ & \\
\hline \multirow[t]{3}{*}{ Tumor grade } & Well-differentiated & $4(5 \%)$ & $3(6 \%)$ & $1(3 \%)$ & 0.2771 & $11(55 \%)$ & $8(53 \%)$ & 0.7704 \\
\hline & Moderately differentiated & $51(61 \%)$ & $30(67 \%)$ & $20(54 \%)$ & & $8(40 \%)$ & $5(33 \%)$ & \\
\hline & Poorly differentiated & $28(34 \%)$ & $12(27 \%)$ & $16(43 \%)$ & & $1(5 \%)$ & $2(13 \%)$ & \\
\hline \multirow[t]{2}{*}{ Mucinous differentiation } & No & $56(68 \%)$ & $31(69 \%)$ & $25(68 \%)$ & 0.8982 & $12(60 \%)$ & $10(67 \%)$ & 0.7372 \\
\hline & Yes & $27(32 \%)$ & $14(31 \%)$ & $12(32 \%)$ & & $8(40 \%)$ & $5(33 \%)$ & \\
\hline Signet ring cells & No & $73(88 \%)$ & $43(96 \%)$ & $29(78 \%)$ & 0.0375 & $17(85 \%)$ & $13(87 \%)$ & 1.0000 \\
\hline & Yes & $10(12 \%)$ & $2(4 \%)$ & $8(22 \%)$ & & $3(15 \%)$ & $2(13 \%)$ & \\
\hline Medullary differentiation & No & $81(86 \%)$ & $44(98 \%)$ & $35(95 \%)$ & 0.5864 & $19(95 \%)$ & $15(100 \%)$ & 1.0000 \\
\hline & Yes & $3(4 \%)$ & $1(2 \%)$ & $2(5 \%)$ & & $1(5 \%)$ & - & \\
\hline Micropapillary component & No & $76(94 \%)$ & $42(96 \%)$ & $34(92 \%)$ & 0.6557 & $18(95 \%)$ & $14(93 \%)$ & 1.0000 \\
\hline & Yes & $5(6 \%)$ & $2(4 \%)$ & $3(8 \%)$ & & $1(5 \%)$ & $1(7 \%)$ & \\
\hline & Unknown & 1 & 1 & - & & 1 & - & \\
\hline Crohn-like response & None & $39(56 \%)$ & $20(54 \%)$ & $19(59 \%)$ & 0.5416 & $10(59 \%)$ & $5(38 \%)$ & 0.2685 \\
\hline & Mild to moderate & $30(42 \%)$ & $17(46 \%)$ & $12(38 \%)$ & & $6(35 \%)$ & $8(62 \%)$ & \\
\hline & Marked & $1(1 \%)$ & - & $1(3 \%)$ & & $1(6 \%)$ & - & \\
\hline & Unknown & 13 & 8 & 5 & & 3 & 2 & \\
\hline Histological heterogeneity & No & $56(68 \%)$ & $33(73 \%)$ & $22(61 \%)$ & 0.2417 & $9(45 \%)$ & $12(80 \%)$ & 0.0461 \\
\hline & Yes & $26(32 \%)$ & $12(27 \%)$ & $14(59 \%)$ & & $11(55 \%)$ & $3(20 \%)$ & \\
\hline & Unknown & 1 & - & - & & - & - & \\
\hline Garland-like necrosis & No & $43(52 \%)$ & $26(58 \%)$ & $17(46 \%)$ & 0.5044 & $10(50 \%)$ & $8(53 \%)$ & 0.1077 \\
\hline & Yes & $20(24 \%)$ & $9(20 \%)$ & $11(30 \%)$ & & $2(10 \%)$ & $5(33 \%)$ & \\
\hline & Focal & $20(24 \%)$ & $10(22 \%)$ & $9(24 \%)$ & & $8(40 \%)$ & $2(14 \%)$ & \\
\hline Growth pattern & Invasive & $52(75 \%)$ & $28(74 \%)$ & $23(74 \%)$ & 1.0000 & $15(79 \%)$ & $10(72 \%)$ & 0.8367 \\
\hline & Expansive and invasive & $15(21 \%)$ & $9(24 \%)$ & $7(23 \%)$ & & $3(16 \%)$ & $3(21 \%)$ & \\
\hline & Expansive & $3(4 \%)$ & $1(2 \%)$ & $1(3 \%)$ & & $1(5 \%)$ & $1(7 \%)$ & \\
\hline & Unknown & 13 & 7 & 6 & & 1 & 1 & \\
\hline TILs & None & $66(80 \%)$ & $36(80 \%)$ & $30(81 \%)$ & 0.8417 & $15(75 \%)$ & $10(67 \%)$ & 0.8628 \\
\hline & Mild to moderate (2/HPF) & $7(8 \%)$ & $4(9 \%)$ & $2(5 \%)$ & & $2(10 \%)$ & $3(20 \%)$ & \\
\hline & Marked (3/HPF) & $10(12 \%)$ & $5(11 \%)$ & $5(14 \%)$ & & $3(15 \%)$ & $2(13 \%)$ & \\
\hline LVI & No & $51(65 \%)$ & $28(65 \%)$ & $23(66 \%)$ & 0.9560 & $11(58 \%)$ & $10(67 \%)$ & 0.7282 \\
\hline & Yes & $28(35 \%)$ & $15(35 \%)$ & $12(34 \%)$ & & $8(42 \%)$ & $5(33 \%)$ & \\
\hline & Unknown & 4 & 2 & 2 & & 1 & - & \\
\hline
\end{tabular}




\begin{tabular}{|c|c|c|c|c|c|c|c|c|}
\hline & & \multirow{2}{*}{$\begin{array}{l}\text { All samples } \\
\qquad(\mathrm{n}=83)\end{array}$} & \multicolumn{2}{|c|}{ Age at diagnosis } & \multirow[t]{2}{*}{$p$-Value } & \multirow{2}{*}{$\begin{array}{c}\text { MSS/ } \\
\text { MSI-low } \\
(n=20)\end{array}$} & \multirow{2}{*}{$\begin{array}{l}\text { MSI- } \\
\text { high } \\
(n=15)\end{array}$} & \multirow[t]{2}{*}{$p$-Value } \\
\hline & & & $\begin{array}{c}>50 \text { Years } \\
\quad(\mathrm{n}=45)\end{array}$ & $\begin{array}{c}\leq 50 \text { Years } \\
(\mathrm{n}=37)\end{array}$ & & & & \\
\hline \multirow[t]{3}{*}{ PNI } & No & $74(94 \%)$ & $40(93 \%)$ & $33(94 \%)$ & 1.0000 & $17(89 \%)$ & $14(93 \%)$ & 1.0000 \\
\hline & Yes & $5(6 \%)$ & $3(7 \%)$ & $2(6 \%)$ & & $2(11 \%)$ & $1(7 \%)$ & \\
\hline & Unknown & 4 & 2 & 2 & & 1 & - & \\
\hline \multirow[t]{3}{*}{ Residual adenoma } & No & $42(75 \%)$ & $20(89 \%)$ & $21(62 \%)$ & 0.5889 & $17(89 \%)$ & $8(62 \%)$ & 0.4434 \\
\hline & Yes & $14(25 \%)$ & $8(11 \%)$ & $6(38 \%)$ & & $2(11 \%)$ & $5(38 \%)$ & \\
\hline & Unknown & 27 & 17 & 10 & & 1 & 2 & \\
\hline \multirow[t]{3}{*}{ Tumor budding } & No & $52(70 \%)$ & $25(63 \%)$ & $26(78 \%)$ & 0.1312 & $12(67 \%)$ & $9(60 \%)$ & 0.6918 \\
\hline & Yes & $22(30 \%)$ & $15(37 \%)$ & $7(22 \%)$ & & $6(33 \%)$ & $6(40 \%)$ & \\
\hline & Unknown & 9 & 5 & 4 & & 2 & - & \\
\hline \multirow[t]{3}{*}{ EMT-like response } & No & $51(69 \%)$ & $27(66 \%)$ & $23(72 \%)$ & 0.5827 & $12(67 \%)$ & $10(67 \%)$ & 1.0000 \\
\hline & Yes & $23(31 \%)$ & $14(34 \%)$ & $9(28 \%)$ & & $6(33 \%)$ & $5(33 \%)$ & \\
\hline & Unknown & 9 & 5 & 4 & & 2 & - & \\
\hline \multirow[t]{3}{*}{ Treatment response } & No & $80(98 \%)$ & $44(98 \%)$ & $35(97 \%)$ & 1.0000 & $20(100 \%)$ & $15(100 \%)$ & - \\
\hline & Yes & $2(2 \%)$ & $1(2 \%)$ & $1(3 \%)$ & & - & - & \\
\hline & Unknown & 1 & - & 1 & & - & - & \\
\hline \multirow[t]{3}{*}{ Angiolymphatic invasion } & No & $52(67 \%)$ & $28(67 \%)$ & $23(66 \%)$ & 0.9299 & $11(58 \%)$ & $11(79 \%)$ & 0.2783 \\
\hline & Yes & $26(33 \%)$ & $14(33 \%)$ & $12(34 \%)$ & & $8(42 \%)$ & $3(21 \%)$ & \\
\hline & Unknown & 5 & 3 & 2 & & 1 & 1 & \\
\hline
\end{tabular}

TILs: Tumor-infiltrating lymphocytes, HPF: high-power field, LVI: lymphovascular invasion, PNI: perineural invasion, EMT: epithelialmesenchymal transition.

approved by Institutional Review Boards at both the University of Ibadan and Vanderbilt University (IRB\# 140219). The blocks were made from biospecimens collected from 2007 to 2014. Following pathology review, we removed mislabeled samples (no CRC), duplicate samples, and samples that did not have enough material for analysis. The remaining 83 blocks were used for pathological and molecular analysis. These biospecimens originated from resection in $54(65 \%)$ cases, biopsy in $26(31 \%)$, and unknown source in three $(4 \%)$

Pathology review. Pathology review was performed at the University of Ibadan and Vanderbilt University and all discrepancies were resolved. Histological slides were reviewed at Vanderbilt for histological type, tumor grade, Crohn-like response, histological heterogeneity, garland-like necrosis, growth pattern, tumor Infiltrating Lymphocytes (TILs), lymphovascular invasion (LVI), residual adenoma, and treatment response. Histological type was determined based on the WHO criteria (7). For tumors with certain differentiation but not meeting the WHO criteria, the percentage of the differentiation was recorded. Histological heterogeneity was determined by significant presence of two histological types $(>5 \%)$. Quality of hematoxylin and eosin (H\&E) staining was also assessed.

MSI testing. MSI was tested using the protocol developed in our laboratory and described in detail elsewhere (8). Briefly, we compared the length and pattern of 10 amplified, fluorescently labeled monoand dinucleotide microsatellite markers (BAT26, BAT25, $\beta$-catenin, D10S197, BAT40, D18S58, D2S123, TGF 3 , D5S346, and D17S250) in tumor and normal adjacent tissue. Only tumors with a minimum of three available markers including at least one mononucleotide marker were considered for analysis. Tumors with $\geq 30 \%$ unstable markers were considered MSI-high, $<30 \%$ as MSI-low, and tumors with all stable markers as microsatellite stable (MSS).

Statistical analysis. All statistical analyses were performed using SAS 9.4 (SAS Institute, Cary, NC, USA). Univariate analysis of continuous variables was performed using $t$-test, and categorical variables were analyzed using chi-square and Fisher's exact tests. Pearson correlation coefficient was used to measure linear relationship between two variables. In all analyses, $p$-values of less than 0.05 were considered statistically significant.

\section{Results}

Our Nigerian sample had almost equal numbers of males and females (48\% and 52\%) with a median age at diagnosis of 53 years (from 16 to 85 years) (Table I). Tumor location distribution in our unselected sample was significantly different from that observed in the USA. The Nigerian sample had an almost four-fold number of rectal cancer cases [66\% vs. $18 \%$ in the USA (9)], while the number of distal colon adenocarcinomas was three times lower in Nigerian patients [11\% vs. $35 \%$ in the US (9)]. Stage information was only available for 27 patients, since many patients had no data on metastases, probably due to lack of follow-up. Close to $60 \%$ of the patients had stage III or IV CRC. Almost 34\% (28/83) of CRC in Nigerians were poorly differentiated. Mucinous adenocarcinomas were also more common in Nigerians 
Table II. Frequency of tumors according to microsatellite instability status in Native Africans and African-Americans from a number of studies.

\begin{tabular}{|c|c|c|c|c|c|c|c|}
\hline \multirow[t]{2}{*}{ MSI status } & \multicolumn{7}{|c|}{ Ethnicity } \\
\hline & Nigeria* & Ghana (4) & $\begin{array}{c}\text { African- } \\
\text { Americans (19) }\end{array}$ & $\begin{array}{c}\text { African- } \\
\text { Americans (20) }\end{array}$ & $\begin{array}{c}\text { African- } \\
\text { Americans (21) }\end{array}$ & $\begin{array}{c}\text { African- } \\
\text { Americans (31) }\end{array}$ & $\begin{array}{c}\text { African- } \\
\text { Americans (22) }\end{array}$ \\
\hline MSS/MSI-low & $20(57 \%)$ & $41(59 \%)$ & $12(55 \%)$ & $29(57 \%)$ & $178(81.2 \%)$ & $66(69 \%)$ & $170(85 \%)$ \\
\hline MSI-high & $15(43 \%)$ & $29(41 \%)$ & $10(45 \%)$ & $22(43 \%)$ & $44(19.8 \%)$ & $29(31 \%)$ & $29(15 \%)$ \\
\hline
\end{tabular}

MSI: Microsatellite instability; MSS: microsatellite stable; *Present study.

(10\%) compared to the US populations $(6.8 \%$ in Whites and $5.4 \%$ in Blacks) (10). Signet ring cell carcinomas were found in $4 \%(3 / 76)$ of all histological types. Overall, $96 \%$ of CRCs had an invasive or invasive/expansive growth pattern, including all mucinous and signet ring carcinomas. Tumorinfiltrating lymphocytes (TILs) were found in $20 \%$ of CRCs and Crohn-like response (CLR) was observed in $44 \%$ of the cases. LVI was observed in $35 \%$ of all CRCs.

Analysis of patients with CRC diagnosed at 50 years or younger showed higher prevalence of stage IV disease $(50 \%$ vs. $13 \%$ ) and poorly differentiated tumors (43\% vs. 27\%), although overall differences were not statistically significant (Table I). Presence of signet ring cell differentiation (10-50\% of tumor) was significantly higher in CRC diagnosed before age 50 years (odds ratio $=5.93,95 \%$ confidence interval $=1.17$ $29.95, p=0.038$ ), although these cases could not be classified as signet ring cell carcinomas, which requires $>50 \%$ of signet ring cells present. Garland-like necrosis occurred in $24 \%$ of all CRCs; $20 \%$ in those patients diagnosed after 50 years, and $30 \%$ in those diagnosed below 50 years.

We found MSI-high in $43 \%(15 / 35)$ of all CRCs in Nigerians, which is comparable with our previous findings in Ghana (41\%) (4) (Table II). MSI-high CRC had significantly lower histological heterogeneity than MSS CRC (20\% vs. 55\% respectively, $p=0.046$ ) (Table I). TILs and CLR were more common in MSI-high compared to MSS CRCs (33\% and $62 \%$ vs. $25 \%$ and $41 \%$, respectively), although not statistically significantly. There were no other significant differences in clinicopathological features, including tumor location, between MSI-high and MSS CRCs. Although not statistically significant, we observed more MSI-high CRC in patients younger than 50 years $(55 \%$ vs. $35 \%$ in older patients).

\section{Discussion}

One of the most prominent characteristics of CRC in native Nigerians is that the majority of the patients present with advanced disease (11). Some researchers have declared that this is not necessarily due to late presentation, but rather more to rapid progression of an aggressive tumor type (12). Higher prevalence of younger patients and scanty knowledge of the molecular biomarkers of CRC in Sub-Saharan Africans also contribute to the challenges in clinical management of CRC in Nigeria (13).

Almost 34\% (28/83) of CRCs were poorly differentiated adenocarcinomas and more significantly, supporting the aggressive nature of these tumors, $96 \%$ of them had an invasive growth pattern. This rate is much higher than the $18.5 \%$ recorded in the USA. This probably explains the twice more common incidence of distant metastases (stage IV) in Nigerian patients (30\% vs. $15.4 \%$ in the USA) (9). High prevalence of poorly differentiated adenocarcinoma in Nigerian patients is probably also facilitated by the absence of CLR and TILs in $56 \%$ and $80 \%$ of CRCs, respectively. Studies have shown that lymphocytic reactions to tumor (TILs and CLR) are associated with improved prognosis among patients with CRC, regardless of lymph node involvement and other clinical, pathological, and molecular characteristics (14, 15). In addition, LVI in 35\% of CRCs in Nigerians correlated with poor differentiation of $34 \%$ of CRCs (Pearson $p<0.0001$ ) and is considered to be a poor prognostic factor leading to lymph node and systemic metastases (16).

A few molecular studies on CRC in native West Africans are available. A pilot study in Ibadan, Nigeria found two MSI-high tumors among five randomly selected CRCs (40\%) (17). Immunohistochemical studies in 26 CRCs in Nigerians showed loss of MMR proteins MLH1 and MSH2 in $23 \%$ of cases (18). Our previous study of 90 CRCs from Ghana (4), a West African country neighboring Nigeria, found $41 \%$ MSI-high CRCs and no BRAF mutations, which is similar to the $43 \%$ MSI-high tumors in our present study in Nigeria and several other studies of MSI in CRC in African-Americans (19-22) (Table II). These findings are in a stark contrast to $10-15 \%$ MSI-high CRC in whites (5). Abdulkareem et al. demonstrated a lower frequency of $K R A S$ and BRAF activating mutations $(21 \%$ and $4.5 \%$ respectively) in Nigerian patients with CRC (23). A recent study identified genes exclusively mutated in AfricanAmericans with CRC (6), which further confirms the 
hypothesis that some aspects of cancer biology, whether due to environmental or genetic factors, are different between African and Caucasian patients with CRC (2).

The rate of signet ring cell carcinomas found here as $4 \%$ of all adenocarcinomas is greater than the $1.2 \%$ found in White and $0.9 \%$ in Black populations in the USA $(10,24)$. It appears that a higher prevalence of signet ring cell carcinomas is associated with the younger age at diagnosis of CRC as observed in Nigerians (53 years) in our study in comparison to older age (70 years) in the USA (2). It is known that signet ring cell carcinomas are more common in younger patients with CRC: at $2.44 \%$ before age 50 years $v s$. $0.93 \%$ after age 50 years $(p<0.0001)$ in the US $(9)$. The presence of signet ring cell differentiation (10-50\%) was significantly higher in Nigerian patients diagnosed with CRC before the age of 50 years. Mucinous carcinoma and signet ring cell carcinoma are more difficult in diagnosis and have a poor prognosis (25), with frequent metastases in multiple sites including the peritoneum and liver (26). Higher prevalence of signet ring cell carcinomas may contribute to the high mortality from CRC in Nigeria.

The overwhelming rectal location of CRC in native Africans, similar to our unselected sample (66\%), has been reported before with no plausible explanation (27-29). It is unusual, considering that our sample had increased prevalence of MSI-high CRC that is typically associated with right-sided location. Among features associated with MSIhigh CRC, we found increased TILs and CLR, expansive growth pattern, mucinous tumors, poor differentiation, and younger age; however, we did not see prevalent right-sided location and absence of dirty necrosis (30). Moreover, we observed less histological heterogeneity in MSI-high colorectal cancer in Nigerians.

We identified unique pathological and molecular features of CRC in Nigeria and found a high prevalence of MSI-high tumors. These findings may have a direct translational importance because patients with MSI-high CRC appear to have ineffectual or even detrimental responses to 5fluorouracil-based adjuvant chemotherapy (16), the mainstay of many chemotherapy regimens for CRC (13). More detailed prospective molecular and genetic analyses are warranted as CRC incidence and mortality continue to increase in Sub-Saharan Africa.

\section{Funding}

Colon Cancer Alliance.

\section{References}

1 Ferlay J, Soerjomataram I, Dikshit R, Eser S, Mathers C, Rebelo M, Parkin DM, Forman D and Bray F: Cancer incidence and mortality worldwide: sources, methods and major patterns in GLOBOCAN 2012. Int J Cancer 136: E359-386, 2015.
2 Saluja S, Alatise OI, Adewale A, Misholy J, Chou J, Gonen M, Weiser M and Kingham TP: A comparison of colorectal cancer in Nigerian and North American patients: is the cancer biology different? Surgery 156: 305-310, 2014.

3 Droz J-P, Carme B, Couppié P, Nacher M and Thiéblemont C: Tropical Hemato-Oncology. Cham: Springer, 2015.

4 Raskin L, Dakubo JC, Palaski N, Greenson JK and Gruber SB: Distinct molecular features of colorectal cancer in Ghana. Cancer Epidemiol 37: 556-561, 2013.

5 Vilar E and Gruber SB: Microsatellite instability in colorectal cancer-the stable evidence. Nat Rev Clin Oncol 7: 153-162, 2010.

6 Guda K, Veigl ML, Varadan V, Nosrati A, Ravi L, Lutterbaugh J, Beard L, Willson JK, Sedwick WD, Wang ZJ, Molyneaux N, Miron A, Adams MD, Elston RC, Markowitz SD and Willis JE: Novel recurrently mutated genes in African American colon cancers. Proc Natl Acad Sci USA 112: 1149-1154, 2015.

7 Bosman FT, World Health Organization and International Agency for Research on Cancer: WHO Classification of Tumours of the Digestive System. Lyon: International Agency for Research on Cancer, 2010.

8 Vilar E, Mukherjee B, Kuick R, Raskin L, Misek DE, Taylor JM, Giordano TJ, Hanash SM, Fearon ER, Rennert G and Gruber SB: Gene expression patterns in mismatch repair-deficient colorectal cancers highlight the potential therapeutic role of inhibitors of the phosphatidylinositol 3-kinase-AKT-mammalian target of rapamycin pathway. Clin Cancer Res 15: 2829-2839, 2009.

9 Stewart SL, Wike JM, Kato I, Lewis DR and Michaud F: A population-based study of colorectal cancer histology in the United States, 1998-2001. Cancer 107: 1128-1141, 2006.

10 Howlader N, Noone AM, Krapcho M, Miller D, Bishop K, Altekruse SF, Kosary CL, Yu M, Ruhl J, Tatalovich Z, Mariotto A, Lewis DR, Chen HS, Feuer EJ and Cronin KA: SEER Cancer Statistics Review, 1975-2013, National Cancer Institute. Bethesda, MD, http://seer.cancer.gov/csr/1975_2013/, based on November 2015 SEER data submission, posted to the SEER web site, April 2016. Bethesda, MD: National Cancer Institute, 2016.

11 Irabor DO, Afuwape OO and O.O. A: The present status of the management of colon and rectal cancer in Nigeria. J Cancer Res 190: 1-7, 2014.

12 van't Hof A, Gilissen K, Cohen RJ, Taylor L, Haffajee Z, Thornley $\mathrm{AL}$ and Segal I: Colonic cell proliferation in two different ethnic groups with contrasting incidence of colon cancer: Is there a difference in carcinogenesis? Gut 36: 691-695, 1995.

13 Pritchard CC and Grady WM: Colorectal cancer molecular biology moves into clinical practice. Gut 60: 116-129, 2011.

14 Ogino S, Nosho K, Irahara N, Meyerhardt JA, Baba Y, Shima K, Glickman JN, Ferrone CR, Mino-Kenudson M, Tanaka N, Dranoff G, Giovannucci EL and Fuchs CS: Lymphocytic reaction to colorectal cancer is associated with longer survival, independent of lymph node count, microsatellite instability and CpG island methylator phenotype. Clin Cancer Res 15: 64126420, 2009.

15 Rozek LS, Schmit SL, Greenson JK, Tomsho LP, Rennert HS, Rennert G and Gruber SB: Tumor-infiltrating lymphocytes, Crohn's-like lymphoid reaction and survival from colorectal cancer. J Natl Cancer Inst 108(8): pii: djw027, 2016.

16 Xiao H, Yoon YS, Hong SM, Roh SA, Cho DH, Yu CS and Kim JC: Poorly differentiated colorectal cancers: correlation of microsatellite instability with clinicopathologic features and survival. Am J Clin Pathol 140: 341-347, 2013. 
17 Adebamowo CA, Adeyi O, Pyatt R, Prior TW, Chadwick RB and de la Chapelle A: Case report on hereditary non-polyposis colon cancer (HNPCC) in Nigeria. Afr J Med Med Sci 29: 7173, 2000.

18 Duduyemi BM, Akang EEU, Adegboyega PA and Thomas JO: Significance of dna mismatch repair genes and microsatellite instability in colorectal carcinoma in Ibadan, Nigeria. Am J Med Biol Res 1: 145-148, 2013.

19 Ashktorab H, Smoot DT, Carethers JM, Rahmanian M, Kittles R, Vosganian G, Doura M, Nidhiry E, Naab T, Momen B, Shakhani S and Giardiello FM: High incidence of microsatellite instability in colorectal cancer from African Americans. Clin Cancer Res 9: 1112-1117, 2003.

20 Ashktorab H, Smoot DT, Farzanmehr H, Fidelia-Lambert M, Momen B, Hylind L, Iacosozio-Dononue C, Carethers JM, Goel A, Boland CR and Giardiello FM: Clinicopathological features and microsatellite instability (MSI) in colorectal cancers from African Americans. Int J Cancer 116: 914-919, 2005.

21 Kumar K, Brim H, Giardiello F, Smoot DT, Nouraie M, Lee EL and Ashktorab H: Distinct BRAF (V600E) and KRAS mutations in high microsatellite instability sporadic colorectal cancer in African Americans. Clin Cancer Res 15: 1155-1161, 2009.

22 Sylvester BE, Huo D, Khramtsov A, Zhang J, Smalling RV, Olugbile S, Polite BN and Olopade OI: Molecular analysis of colorectal tumors within a diverse patient cohort at a single institution. Clin Cancer Res 18: 350-359, 2012.

23 Abdulkareem FB, Sanni LA, Richman SD, Chambers P, Hemmings G, Grabsch H, Quirke P, Elesha SO, Banjo AF, Atoyebi OA, Adesanya AA, Onyekwere CA, Ojukwu J, Anomneze EE and Rotimi O: KRAS and BRAF mutations in Nigerian colorectal cancers. West Afr J Med 31: 198-203, 2012.

24 Hyngstrom JR, Hu CY, Xing Y, You YN, Feig BW, Skibber JM, Rodriguez-Bigas MA, Cormier JN and Chang GJ: Clinicopathology and outcomes for mucinous and signet ring colorectal adenocarcinoma: analysis from the National Cancer Data Base. Ann Surg Oncol 19: 2814-2821, 2012.
25 Nitsche U, Zimmermann A, Spath C, Muller T, Maak M, Schuster T, Slotta-Huspenina J, Kaser SA, Michalski CW, Janssen KP, Friess H, Rosenberg R and Bader FG: Mucinous and signet-ring cell colorectal cancers differ from classical adenocarcinomas in tumor biology and prognosis. Ann Surg 258: 775-782, 2013.

26 Hugen N, van de Velde CJ, de Wilt JH and Nagtegaal ID: Metastatic pattern in colorectal cancer is strongly influenced by histological subtype. Ann Oncol 25: 651-657, 2014.

27 Amegbor K, Napo-Koura GA, Songne-Gnamkoulamba B, Redah $\mathrm{D}$ and Tekou A: Epidemiological and pathological aspects of gastrointestinal tumors in Togo. Gastroenterol Clin Biol 32: 430434, 2008.

28 Edino ST, Mohammed AZ and Ochicha O: Characteristics of colorectal carcinoma in Kano, Nigeria: an analysis of 50 cases. Niger J Med 14: 161-166, 2005.

29 Irabor D and Adedeji OA: Colorectal cancer in Nigeria: 40 years on. A review. Eur J Cancer Care (Engl) 18: 110-115, 2009.

30 Greenson JK, Huang SC, Herron C, Moreno V, Bonner JD, Tomsho LP, Ben-Izhak O, Cohen HI, Trougouboff P, Bejhar J, Sova Y, Pinchev M, Rennert G and Gruber SB: Pathologic predictors of microsatellite instability in colorectal cancer. Am J Surg Pathol 33: 126-133, 2009.

31 Brim H, Lee E, Abu-Asab MS, Chaouchi M, Razjouyan H, Namin H, Goel A, Schaffer AA and Ashktorab H: Genomic aberrations in an African American colorectal cancer cohort reveals a MSI-specific profile and chromosome $\mathrm{X}$ amplification in male patients. PLoS One 7: e40392, 2012.
Received March 14, 2017

Revised April 5, 2017

Accepted April 11, 2017 